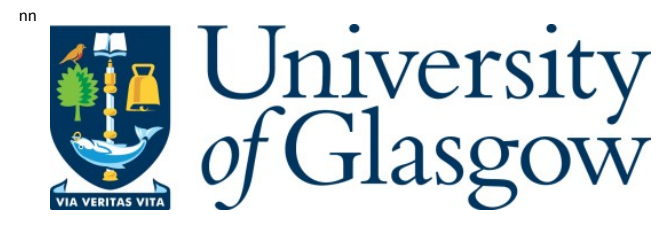

M ulvey, G. (2015) Refugee integration policy: the effects of UK policymaking on refugees in Scotland. J ournal of Social Policy.

Copyright @ 2015 Cambridge U niversity Press

A copy can be downloaded for personal non-commercial research or study, without prior permission or charge

Content must not be changed in any way or reproduced in any format or medium without the formal permission of the copyright holder(s)

http://eprints.gla.ac.uk/102302/

Deposited on: 05 February 2015

Enlighten - Research publications by members of the University of Glasgow http://eprints.gla.ac.uk 


\section{Refugee integration policy; the effects of UK policy-making on refugees in Scotland}

\section{Abstract}

While the concept of migrant integration is a contested one, national, sub-national and local governments over the past 40-50 years have professed support for integration in various forms. However, practical measures have been rare with broad race relations policies from the 1960s being the primary means of 'inclusion'. Under New Labour refugees were identified as a migrant population with particular challenges and they have been the only migrant group subject to specific integration programmes. Nevertheless, policy and rhetoric about asylum seekers and refugees more generally have tended to operate against integration and have made it increasingly difficult for refugees to rebuild their lives. This paper examines refugee integration from the perspectives of refugees themselves, using both qualitative and quantitative methods. It also looks at the governance of integration in Scotland with Scottish distinctiveness vis-à-vis the UK highlighted. The article suggests that the consequences of broader UK Government policy around asylum and refugee issues negates any positive support in the form of refugee integration programmes and actively inhibits integration.

Refugees, Integration, Policy, Scotland, UK

\section{Introduction}

The existence of integrated communities within the UK has generally been considered to be a 'public good' and has been a policy goal of all levels of G overnment over much of the last half century. However, what this means is contested, ranging from various forms of assimilation and acculturation to the multiculturalism inherent in much race relations policy. While politicians have often exhibited contradictory impulses regarding integration, the academic debate too has been shrouded in controversy and debate (Spencer 2011). These debates are also complicated by the devolved settlement in the UK, meaning that areas of policy that are formally reserved are often shared among different levels of government who can have opposing policy positions (Bowes et al, Scholten 2013). Nevertheless, with very few exceptions integration under whatever guise is viewed as a good thing.

Migration policy has been even more complex and controversial, encompassing broad economic policy, all classic areas of social policy as well as human rights. This paper seeks to link immigration policy, specifically asylum policy, to immigrant policy in the form of integration, and does so within a multi-level system of Government. The question the paper seeks to address is; is it possible to have a successful immigrant integration policy with the 
present immigration policy? The paper looks specifically at refugees in Scotland as a means of doing so, alongside some suggestions about the relevance of the multi-level context in which it takes place.

In multi-levelled forms of Government, whether federal or not, there can be policy tensions between levels of Government that can lead to divergence (Cairney 2012) or decoupling (Scholten 2013). There is evidence within a fairly narrow range of policy issues that divergence between Westminster and Holyrood has occurred. There has also been some contestation between Holyrood and Westminster on migration issues. The Scottish Executive's (as then was) Fresh Talent initiative aimed at allowing overseas students graduating from Scottish universities to stay and work in Scotland. However, the Home Office were reluctant to make concessions based on Scotlands differing demographic needs and this led to conflict of powers between the levels of government (Birrell 2009). Perhaps of more relevance was the blurred boundaries between reserved asylum policy and devolved responsibility for child welfare that played out in a dispute over the forced detention of asylum seeking children, or children of asylum seekers and prompted Scotland's Children's Commissioner to state that "immigration may well be a reserved issue, but children aren't" (Mooney and Williams 2006). More generally there have been regular complaints within the Scottish Parliament that the concordat between UK and Scottish Governments has not led to the Home Office being open to engagement with Members of the Scottish Parliament (MSP) over constituency issues. That is, MSPs are approached by constituents who are migrants about status or visa issues and are told that the Home Office will not speak with them about reserved policy matters. This article lends some support to arguments about diverging policy, but does so without specifically comparing policies in the different jurisdictions. It is enough to highlight some of the differences in policy architecture. Linked to divergence is decoupling which has thus far been primarily viewed as an organisational rather than policy matter whereby policy and practice within an organisation are seen to diverge. However, if Pierson is correct that policies should be viewed as institutions (Pierson 2006), then policy decoupling opens up a different way of viewing contestation in relation to multi-level politics. Divergence can emerge between levels of Government but can also be seen in some of the consequences of one policy area on another, both within and between governments as well as between devolved and reserved policy.

UK policy regarding refugee integration has had conflicting rationales. Under the previous Labour Government only refugee integration in the form of the Strategic Upgrade of National Refugee Integration (Sunrise) and Refugee Integration and Employment Service (RIES) received formal government support (S pencer 2011 215). Thus the particularity of refugees was recognised, and both Sunrise and RIES provided support in relation to employment and 
housing, support removed by the Coalition Government. However, a myriad of policies impact on refugees' ability to 'integrate' that operate against these integration programmes. For example five-year refugee status put temporal limits on refugees' automatic time in the UK, and thus inhibited their ability to make plans for the future (Stewart and Mulvey 2013). Furthermore the overall negative policy direction in relation to asylum also had significant longer term effects with regard to refugee integration. The effects of immigration policy are linked to integration.

It is within this broad political context that this paper is situated, with a specific focus on refugee integration in Scotland. Knowledge of refugees' integration in Scotland is sparse, although the Scottish sample of the Survey of New Refugees gives some insight into employment, housing and language issues. This paper provides empirical data about refugee lives in Scotland, and relates it to central Government policy impacts. The paper focuses on the interaction of policy and its impacts in just a few key areas. These have been selected as areas most indicative of the policy-impacts nexus. The paper argues that despite support for refugee integration through a variety of Government schemes, other aspects of Government policy actively inhibit that integration.

\section{Methods}

This paper is based on data from a mixed methods study of refugees in Scotland conducted between 2009 and 2013. The main survey was conducted between October 2010 and May 2011, and elicited 262 responses with forty follow up interviews in spring/summer 2011. This was followed by a re-issuing of the questionnaire between November 2011 and February 2012 followed by further thematic interviews. The quantitative data reported here comes from the larger response numbers in questionnaire 1 as there was considerable atrophy in participant numbers. The qualitative data comes from both initial and follow-up interviews conducted in 2011 and 2012. All interviewees were given a code and are referred to in this article by that code.

The sample is $62 \%$ refugee and $31 \%$ asylum seeker, with the remainder a mixture of $B$ ritish citizens and people who were unsure of their status. Most of the demographics broadly reflect what is known of the refugee population in Scotland, although there is an overrepresentation of women at $54 \%$ of the overall sample. Refugees tend to be young, $76 \%$ of participants were 40 years of age or younger, coming predominantly from countries with a history of producing refugee movements. The largest national groups were from China, Iran, Iraq, Eritrea and the Democratic R epublic of Congo. The year of arrival of participants was spread fairly evenly with around half arriving between 2007 and 2011 and rest arriving before 2007. 
There are a couple of significant limitations to the data presented here. The first of these concerns language. Although questionnaires were translated into all of the appropriate languages, the fact that written questionnaires were the starting point of the study meant that refugees who are not literate in the first language were not included. The project also relied on colleges, and community and voluntary organisations to distribute surveys. Individuals not involved or known to any of these groups have not been part of this study. While these are serious limitations it is unlikely that 'complete' data would change the main themes of the paper. The data presented here concern those with some community support, those who have higher literacy levels and those who are more engaged in the city they live in. This might suggest that the reality for those not involved in the research show similar but worse outcomes than those reported here and therefore do not question the general theme of negative policy impacts.

\section{What is known about integration?}

It is neither the intention of this article to uncritically accept the concept of integration nor within its scope to fully engage in debates about its utility. As a piece focussing on policy and its effects, it is to some degree framed by that policy. Both the UK Government and the Scottish Government use the term integration, although there appear to be significant differences in relation to how it is viewed by these Governments. Integration as a concept has also been a prominent one at the EU level from the Tampere Programme in 1999 onwards. Nevertheless, a few words of caution are required. First of all, much of the UK Government's focus on 'Britishness' and its relationship to migration and integration is based around the notion of making migrants less different from the dominant culture (Kostakopoulou 2010, Threadgold and Court 2005). There is a sense that integration can sometimes therefore mean assimilation. Secondly integration can be subject to considerable conceptual stretching. It is used to describe a wide variety of processes and is used variously as both a means and an end, highlighting processes and outcomes which may or may not be explicitly linked.

Another important criticism of the concept of integration is that it can individualise the structural. The implication is that non-integration, however that is measured, is due to individual action or inaction rather than due to structural matters. This also means that policy that seeks to integrate can often individualise a collective problem by, for example, focusing on an individual's employability rather than structural labour market barriers. Linked to this, as Miles forcefully argues, the concept of integration can be ideological in, for example, having assumptions that migrants have not been a part of creating state and social 
formations that they are now to be integrated into (Miles 1993), although this critique is perhaps less salient when the focus is on new arrivals.

Much international work on integration posits the existence of 'national models' (Favell 1998, J oppke 1999), although the differences between models should not be over-stated (Favell 1998, J oppke 2007). However, as Penninx et al (2008) suggest immigration within countries is also worth analysis. Zincone and Caponio (2006), for example, have looked at both how policy is made and at what levels of Government in the case of Italy, with the non-national dimension focusing primarily on a policy network approach. Scholten has compared municipal authorities approaches to integration with each other and with the national position, though his work looked at interactions between levels of Government rather than any impact upon migrants.

There has also been research on the impact, direct or otherwise, of policy on migration generally and refugees particularly in B ritain. Phillimore suggests that "while integration has been the focus of some conceptually based discussion in social science literature, little attention has been given to the ways in which social and public policy can facilitate, or militate against, integration"(Phillimore 2011 577). How these factors play out in the lived experiences of migrants and refugees, has been subject to little empirical enquiry, and knowledge of refugee integration, particularly in Scotland, has been somewhat patchy. There has also tended to be something of both a quantitative and an economic bias to research thus far (see Sim 2009, Smyth and Kum 2010 and Stewart 2007 for qualitative work on refugees in Scotland).

For Bloch, employment remains one of the key elements of successful settlement, allowing economic independence, which is known to have mental health effects, aiding language learning and creating contacts or bridges with the host society (Bloch 2000 86). However, Threadgold and Court point out that refugee unemployment is high, $70 \%$ in one study in the UK in 2002 (Threadgold and Court 2005 56). Research suggests that employment problems are partly due to a 'tendency to place emphasis on human capital rather than the structural, physical and psycho-social factors' (Ibid 25), including inequalities and discrimination related to race and immigration status, low levels of English language proficiency and nonrecognition of professional qualifications and employment experience acquired outside the UK (Bloch 2007 557).

Housing was prioritised as the most important 'domain' of integration by refugees in the work of Phillimore and Goodson who point to the particularity of refugeeness regarding housing issues. 'For those seeking refuge, it could be argued that the importance of finding a home is particularly symbolic as it marks the end of a journey and the point at which refugees can 
start to consider their wider needs' (Phillimore and Goodson 2008 316). E ducation is also highlighted in Phillimore and Goodson's research. They found education to be the third most important factor among refugees, just behind housing and employment. 'However, if the importance of learning English is included, then education becomes the most important factor to aid settlement' (Phillimore and Goodson 2008 317). With regard to language, Cebulla et al also find a link between English language acquisition and the likelihood of being in employment (Cebulla et al 2010 2).

For this paper integration is used as a broad concept that reflects Ager and Strang's (2004) 'Indicators of Integration' framework, meaning there are multiple overlapping factors that cumulatively either facilitate or hamper integration. These include employment (access, type, security and match to skill levels), housing (conditions, area and future options), education (in country of origin and here, including access to language learning where necessary), health (pre-existing conditions, access and experiences) social connections, cultural knowledge and the importance of rights and citizenship. Ager and Strang point to the importance of rights and citizenship to integration processes (Ager and Strang 2008). Indeed, for them it is the foundation on which integration can be built. While not having citizenship can inhibit inclusion in, for example, the labour market, Bloch also points out that 'anything less than full citizenship will impede settlement because members of the host society do not see the migrant as part of that society' (Bloch 2000 78). Thus the perceptions of the general population have an impact on integration processes, as well as practical issues concerning the absence of rights. It is beyond the scope of this paper to examine all of these factors. The choice of issues should not be taken to imply that they are to be prioritised over other issues, it simply reflects both restrictions in space and some of the elements of integration that perhaps have clearer policy dimensions.

\section{The policy context}

For many scholars there has been ideological continuity in terms of the relationship between immigration control and integration among policy-makers since at least the 1960s (see for example Hansen 2000, J oppke 1999 and Solomos 2003). Race relations policies were the internal policy practice while strict controls of numbers formed the external plank of this dual approach, although governments' ability to control numbers is not as easy as assumed, as the Coalition Government in power since 2010 have found. The large increases in the number of labour migrants since the 1990s question some of the historic external part of the dual approach for wanted refugees, although it has broadly held regarding unwanted refugees, with protection being predicated on strict control of numbers alongside the practice of making life in the asylum process less comfortable. The aim of the asylum process has 
been to discourage the assumed 'pull' of ease of life, based on the idea for that for those 'genuinely' fleeing persecution, hardships are tolerable (see J ack Straw Hansard J uly 27th 1998 Col 46).

However, numbers of applications for asylum fluctuate according to events around the world and individuals' ability to get to the UK. Applications in the UK reached a peak of 84,130 in 2002 before falling to 21,785 in 2012 . This does not suggest that need reduced; just that policy and practice had made it increasingly difficult to get to the UK in order to apply for asylum. Refugees countries of origin reflects international conflict with the top three countries that asylum applicants in the UK came from in 2012 being Iran, Pakistan and Sri Lanka.

In 1999 the UK Government introduced a new practice of dispersing asylum seekers around the country in order to reduce pressure on the south east of England where most asylum seekers arrived. Glasgow City Council became not just the only Scottish local authority to take part in dispersal; it was also the single largest local authority in the UK to take part in terms of the numbers of asylum seekers. This meant that from 2000 approximately $10 \%$ of the UK's total asylum application numbers were dispersed to Glasgow, totalling an estimated 20,000 (Shisheva et al 2013). In 2012 the three countries from which the majority of the 1029 asylum seekers in Scotland came were Eritrea, Iran and China.

For those who manage to arrive and are recognised as refugees, policies aimed at integration have tended to be aimed at specific areas, forms or domains of integration. Support in the form of actual policy has perhaps been most prevalent in areas of structural integration through educational programmes, including English language provision, and employment support.

However, refugee integration should be conceptualised as a transversal or polycentric policy area, covering at the very least immigration, employment, housing, health, education, community planning, naturalisation and citizenship, policing, national security and foreign policy, and operates across multiple layers of government. Thus far, however, unlike some other transversal policies such as social inclusion/exclusion, it has seldom been treated as suchlike integration "social exclusion is a complex and multi-dimensional process" (Levitas et al 2007 9), encompassing health, employment and employability, housing, education and many others. However, the Governments solution to exclusion has been an individualised movement from the periphery to the centre rather than structural change. Thus individualisation of a collective issue means there can be a gap between what problems exist, and what policy seeks to alleviate. Assumed policy problems of lack of inclusion or 
indeed integration, are related by policy and practice to individual capital (see Dorey 2010 on blaming the poor for their own poverty).

Nevertheless, under New Labour there was some focus on refugee integration. Full and Equal Citizens was published in 2000 and was the Governments first refugee integration strategy. For Spencer, one impetus was the desire to have some counterweight to the negative and restrictive asylum measures being simultaneously undertaken (Spencer 2011 216). The stated aim was to help refugees access jobs, benefits, accommodation, health, education and language classes, as well as encouraging community participation. This contributed to the Department of Work and Pensions in 2003 publishing Working to Rebuild Lives, with a focus on support in accessing the labour market, highlighting the transversal nature of refugee integration. In $2005 \mathrm{Full}$ and Equal Citizens was superseded by Integration Matters. This provided some monitoring of integration and for the first time included funded refugee integration programmes.

The Sunrise programme began in 2005 to provide individual casework support to newly recognised refugees in relation to housing, employment, benefits and financial advice, access to English language tuition and information on the process of family reunion (S tewart 2009 7). Support was intensive and lasted 28-days and was replaced by the Refugee Integration and E mployment Service (RIES) in 2008 with a narrower but longer-term focus. RIES maintained the caseworker approach but was more limited in providing support in employment and education and was offered to all newly recognised refugees for a year. Both of these programmes were contracted out to third sector organisations. As Spencer points out, the level of support provided in each of these programmes was never enough to address the disproportionate disadvantage facing refugees (Spencer 2011 216). Indeed the funding for refugee integration accounted for less than $1 \%$ of the overall spend on asylum and refugees, 'managing migration but not managing settlement' (McG hee in Somerville 2007 177). In addition, UK governments have been explicit that integration should only begin after an individual is recognised as a refugee. Thus those in the process, some for a long time, were not subject to any integration measures.

Anti-integration measures, or at least measures which had discernible negative impacts on integration, were numerous under the previous and present Government. To name just one, in 2002 the Labour Government removed the right to work, or the employment concession as it was called, on the false premise that it acted as a pull for labour migrants to claim asylum (see Robinson and Segrott 2002 and Crawley 2010). However employment not only provides financial independence, and with it improved health outcomes, it also acts as a key socialising venue (Bloch 2000, Mulvey 2013). The denial of the right to work therefore 
operated against integration and also acted to boost the negative asylum discourse, reinforcing false arguments about pull factors while simultaneously emphasising the fact that asylum seekers relied on benefits.

More recently the coalition Governments' approach has broadly reflected their overall political philosophy, with an assumption of integration not requiring central government support. Instead integration is 'promoted' through five broad aims, those of social mobility, participation, responsibility, common ground and combatting extremism. What all of these themes have in common is that the onus is on 'them' to integrate with 'us' (DCLG 2012).

The status of the individuals involved is also of importance and has gone through a number of changes in the last decade or so. There have been less grants of discretionary leave, that is, those recognised as in need of protection but who are outside the auspices of the Refugee Convention. In addition, from 2006 refugee status included the 'cessation clause', meaning refugee status was now granted for just 5-years. Cases were to be kept under review and at the end of the 5-years refugee status would either be renewed or removed. In practice the vast majority have had their status renewed but have nevertheless lived through further 5 -years of uncertainty.

There are also varying levels of government with a role in refugee integration. Indeed Hammar's recognition of the difference between immigration policy and immigrant policy (Hammar 2006) is of particular relevance in the case of refugee integration in Scotland (see Scholten 2013 on the multi-level governance of integration). Outside of entry issues and prior to settlement and naturalisation processes most immigrant policy, such as health, education, social work and housing is devolved (see Bowes et al 2009 on devolution in relation to asylum issues). Nevertheless the restrictions placed on asylum seekers by reserved policy have enduring impacts, many of which are subsequently dealt with by a combination of the Scottish Government and Glasgow City Council.

W ithin devolved policy, the Scottish government, including its predecessor the Scottish Executive, have taken a symbolically different approach to refugee integration. That is, beyond the reserved powers that set rules for the asylum process, the Scottish Government view is that they will use what powers they have to encourage and facilitate integration as soon as an asylum seeker arrives in Scotland. This means, for example, in contrast to policy in Westminster, those in the asylum process in Scotland can access further education, that healthcare remains available to those whose cases have been refused but who remain in the country, that funds are provided for both ESOL and for community organisations supporting integration, and that the rules on access to social housing in Scotland do not have the restrictions of requiring a 'local connection'. There is also a different nuance whereby the 
Scottish Government view integration as a two way process rather than something newcomers must do, again contrary to the focus on Britishness and British values at Westminster.

Thus the policy context into which refugees and asylum seekers attempt to integrate is complex and often contradictory. Policy areas interact with one another, with the status of individuals and with the constitutional settlement to create an environment that can be difficult to comprehend and which often appears to lack coherence.

\section{The Effects of Policy and Practice on Refugee Integration in Scotland}

The rest of this paper focuses on the largely inhibiting effects of UK policy on the lives of refugees in Scotland. Accepting some of the cautions highlighted by scholars about the concept of integration, problems highlighted are not located in individualised processes but in some of the structures and processes that operate to exclude. These suggest that integration is at the very least very difficult within the parameters of present immigration policy.

\section{Policy, time and integration}

Policy and practice have enduring effects on temporal elements of integration with numerous time-lags inhibiting quick integration. Refugees in this study talked of time waiting, for refugee status, for work, for suitable homes and to have security of stay. This is not surprisingly most profound as people go through the process but is also evident post status. Table 1 shows how long it took refugees to be recognised as such.

\section{Table 1 - Time to refugees status}

Table 1 includes only those with refugee status and shows that despite considerable focus from what was formerly the United Kingdom Border Agency (UKBA) time in the process remains an issue. While there has been some quickening of the asylum process, and this brings with it its own problems, in each year of arrival in this study, up to and including 2009, over $40 \%$ of refugees had been in the process for a year or more. Some of the effects of these time periods are highlighted later in this paper

There are also temporal issues in relation to housing where new and more established refugees alike often wait long periods of time in order to access appropriate housing, leaving many in temporary accommodation for considerable lengths of time. On being recognised as refugees, individuals are required to vacate their Home Office provided accommodation and access appropriate housing within 28-days, a timescale that ensures the majority become 
homeless and are provided with temporary accommodation prior to securing more permanent housing. It is widely recognised that this 28-day 'move-on' policy is too tight, but the UK Government has thus far refused to countenance change. Local authorities are then required to deal with actual or potential homelessness. Nearly $10 \%$ of refugees in this research were in temporary accommodation at the time of the first questionnaire, and a significant minority were in this costly form of housing for over a year. This contributed to large numbers of research participants viewing their housing status as transient, making local integration less of a priority. One man, who had been homelessness for 18 months described his reliance on friends 'I've been homeless for a year and a half and one time six months ...... Sometimes it's difficult, sometimes the friends can't handle me anymore because of finances and people don't have enough money as well, people just get status and it's not working, there's not enough money' (E606).

Among both refugees and asylum seekers there is also considerable housing turnover and this negatively impacts upon local integration. Table 2 shows that over a third of respondents had lived in their present accommodation for a year or less. For those in the asylum process this was due to the Home Office moving people around their housing estate, while for refugees it often concerned a lack of knowledge of the options they had available to them, a lack of understanding of the different localities in the city and a desire to take anything in order to get out of temporary accommodation. One man described the process of trying to access social housing, 'They give you the first offer and if you refuse that, they give you a second one. If, after that, you refuse, then they don't help you anymore. So in effect, you have to accept the second offer.... I wouldn't have chosen to live there' (E137). Additionally, refugees with more stable accommodation are concentrated in social housing, with no owner-occupiers, just $11 \%$ renting privately and $6.5 \%$ living with friends.

\section{Table 2 - Time in present housing}

Refugees arrive with varied educational backgrounds with $42 \%$ of research participants having 13 years or more formal education, higher than the UK population as a whole whose mean figure stands at 12.6 according to the OECD. However, almost $26 \%$ have under 10 years of formal education. For the more educated refugees the level at which qualifications are subsequently converted leaves many faced with a decision regarding whether to try to upgrade qualifications in order to access the labour market at an appropriate level, or whether to effectively forego past skills and qualifications and look for employment where it is seen as being available, usually in low-paid, low-skilled work. One woman, for example, stated that "it's very difficult to find a job. Because I was a lecturer at university. I was a 
psychologist, counsellor and researcher. My job is difficult and hard to find something qualified to this kind of job" (E 33). She had taken the decision after a number of years trying to find work commensurate with her skills to look at more menial types of employment. Another stated that the reason for such choices are that 'we have to look for jobs where there are jobs available' (E 137), a pragmatic response but one that can lead to underemployment in terms of both skills and hours.

Added to this problem is the time spent trying to access the labour market and the barriers to such access. Despite a wide variety of skills and qualifications, Table 3 shows that just 20\% of those with the right to work were in some form of paid employment, primarily in low paid, low status and insecure jobs, with some evidence of zero-hours contracts.

\section{Table 3 - Employment status}

At least part of the problem in policy terms relates back to the removal of the right to work from those in the asylum process in 2002. The absence of the right to work delays the practical acculturation that often comes with employment. Employment was seen by refugees as having social as well as financial integrative functions. 'We have to understand that it's not an easy process and that we have to confront these difficulties in order to integrate.... the biggest problem for people coming to this country is finding a job. And it does seem as if there's a barrier in the job field' (E137).

A large proportion of asylum seekers arrive in the UK at an age where careers are normally beginning to be thought through and developed. Some $75 \%$ of respondents in this study were under the age of 40 at the time that they completed the first questionnaire. The barriers to employment faced by asylum seekers and refugees means these formative years are often spent in enforced idleness, with long term effects on future employment chances and for well-being more generally. O ne man stated that 'I'm 35 and I'm sitting.... .I've got qualifications... I'm a healthy person, I can do anything, and that's being wasted' (E 750). What is more, the long-term costs of not being able to access the labour market are well established and have been the focus of considerable Government attention (see for example the numerous welfare-to-work programmes under New Labour and welfare reform under the Coalition Government). Thus asylum policy sits in contradiction to other stated Government aims of moving people from benefits into work.

\section{The Asylum process and its effects on integration}


The asylum process, a process that involves most asylum seekers first institutional and relational experiences in Britain, has had a profound effect on those subjected to it. For those in the asylum system for long periods of time the impacts are more obvious, but these effects are very often just the general asylum experience in elongated form. Asylum seekers are subject to a multitude of restrictions which prevent their engagement with mainstream society. These limitations have knock on effects in many if not all of the domains of integration for those recognised as refugees.

The effects of the institutional assumptions made of applicants by state bodies, the 'culture of disbelief' within the asylum system is raised by many refugees and asylum seekers (Souter 2011). Refugees talk of the impact of going over traumatic experiences and events and encountering this disbelief through questioning the credibility of statements made. One refugee explained it thus, 'It's like, you see, I'm a sick person, if I tell you something ..... then you tell me I'm a liar in my face' (E 279). The burden of proof is on the applicant to prove that they are telling the truth rather than the decision-maker to prove otherwise, contrary to most other legal processes in the UK. This can have a profound effect on the ability of refugees to subsequently be open to new people and experiences, demonstrating that Government behaviours can have enduring effects. One interviewee expressed this view succinctly. 'I know people in Scotland are very good, apart from the Home Office' (E681). Thus the lack of welcome for asylum seekers, not a population that the UK Government seeks to integrate continues to affect the views and experiences of refugees, a population the UK Government says that it does want to integrate.

All of these effects appear to combine to impact on the health of asylum applicants. Although respondents self-rated their health relatively highly with 59\% describing it as either excellent or good (compared to $75 \%$ of the Scottish population in the Scottish Household Survey 2010), this masks some significant health issues. When comparing refugees to asylum seekers over $64 \%$ of refugees describe their health as excellent or good compared to just $46 \%$ of asylum seekers, suggesting that the process itself contributes to ill-health. This is even starker when looking at mental health and well-being. Using the 14 questions in the Warwick/E dinburgh scale of mental health and well-being (WEMWBS) the mean well-being score for asylum seekers is well below that of refugees (see table 4). Women in the asylum process in particular indicate very low WEMWBS scores, lower than the lowest economic quintile of the overall Scottish population (Given 2008). Table 4 therefore indicates that asylum seekers have lower self-rated mental health and well-being than refugees, but also that this is most acute for women. One woman related her mental health problems them to her experiences in the asylum process, 'that was the hardest period in my life. I will never, 
never forget..... because the problem started there, and after that developed. But now its ok. Partly you find medication and you find GP" (E 751). It is also important to note that while many refugees 'recover' and report better health once no longer in the asylum process and on receiving treatment, others develop longer-term health problems that are an ongoing social and financial cost to the health service.

\section{Table 4 - Warwick/E dinburgh scale of mental health and well-being}

These research findings suggest that present immigration policy and practice is having a negative effect on the lives of refugees and asylum seekers in the UK. Poor employment outcomes, lack of housing stability and evidence of health problems all suggest that policy is actively inhibiting integration, however that is measured. The longer term costs to both the individuals involved and to the public purse are not easily quantifiable but are likely to be both substantial, and shared between governments that have created the immigration system and other levels of government that have responsibility for much of the social cost. Thus the governance and costs of policy are inherently multi-level.

\section{Discussion and Conclusion}

While relatively little is known about the interaction between asylum policy and the lived experiences of those subjected to these policies, this paper links the two directly. The evidence suggests that more attention should be paid to immigration policy in relation to its multifaceted impacts on immigrant or integration policy. Such a field of study could learn from some of the work conducted in other transversal policy areas such as social inclusion/exclusion (Levitas 2005). Indeed the individualisation of the concept of integration in policy terms has considerable connections to that of social exclusion and the various levels of government involved is also suggestive of commonalities. Links between these fields of study could prove fruitful both conceptually and empirically.

One example of the political crossover is the suggestion in this paper that negative impacts of policy have much broader deleterious effects than a focus on individual capital allows for. For example, despite varied backgrounds and experiences, some with English language skills before arrival, some with no English, some very well educated and some with no formal education, some with high-skilled employment backgrounds and some with no employment history, the negative impacts of policy on employment appear to be largely universal. This being the case, a focus on the individual, with its implicit assumption that lack of integration, like inclusion, is down to that individual and his or her behaviour is unlikely to have positive effects. In the age-old debate about structure and agency, the structure is receiving too little 
attention in integration policy. The following quotes signify both the impact of the denial of the right to work and some of the impact of not finding work. Regarding the right to work, one man stated that 'they give me status after eight years, its means during these eight years it means like you did nothing and you lost your age..... when you were in your thirties is the time when you're starting to build your career, so for you, you weren't allowed' (E 752). The struggle to access work is then summed up by one refugee thus, 'It makes you - I don't know how to say that - is it rejected?... ust useless yeah. As the time passes, you just get used to being unemployed......if you know the benefits of the work, you try hard to get back to work because it makes your life.... Valuable, it makes your life more valuable' (E536).

The contradiction between a policy approach that celebrates integration but that simultaneously makes integration increasingly difficult suggests therefore that either integration is not a serious aim of policy, that other policy goals are undermining it, or a combination thereof. Without entering into longstanding debates on rationality and policymaking, one of the guiding principles of policy, as far as is possible, should be to prevent future problems arising as a direct result of policy. There is evidence here and elsewhere (Somerville 2007, Spencer 2011, Castles 2004, Cohen 2006) that the lack of rationality has allowed policies to develop that have been short-sighted at best and completely contradictory at worst. Policy-making that does not reflect the importance of prevention, and therefore creates problems that future policy will have to deal with goes against much of what is known about what constitutes 'good' policy making (see for example the Christie Commission 2011) and is evident both in health and employment outcomes for refugees. The picture is further complicated by the policy or departmental siloes that exist in UK politics, meaning, for example, that the results of Home Office policy and practice will often be met by either other UK government departments, or in many cases by sub-national government departments.

More academic focus on the policy effects of immigration on integration would also be able to contribute to and learn from work about multi-level governance and inter-governmental relations. Transversal policies have impacts across all levels of government and some of the policy process literature that posits an implementation gap, for example, could learn from such work, particularly due to contests around policy competences being about more than just implementation. This also has the potential to contribute to recent work from scholars such as Pierson (2006) and Weir (2006) about political contestation but with an intergovernmental focus. Viewing sub-national and local government as mere implementers of reserved or central government policy risks losing the importance of political difference between levels of government, and in the UK case appears to assume a clearer division between what is reserved and what is devolved than is the case. 
Many of the policies described above have been shown to have had negative impacts upon refugees living in Scotland, and the costs subsequently accruing from these effects are met by a combination of the devolved authority and the local authority, a devolution of penury as Mitchell would have it (Mitchell 2002). Thus policy with regard to refugees is not simply reserved or devolved. Instead there is a marbling of responsibilities in different areas and at different levels, sometimes linking and overlapping, but sometimes paying little cognisance to the transversal nature of policy. For example, housing and health are devolved matters, but the reserved asylum process has a profound impact on both. The devolved institutions then have to address the outcomes of that reserved policy.

The problems that arise are not just intergovernmental but also intra-government. At present reserved UK immigration policy is having contradictory impacts not only on sub-national levels of government, but on central government policy itself. The negative impacts of immigration policy on the lives of immigrants have been highlighted in this paper. Whether refugees feel that they can integrate into a new neighbourhood, city or country is clearly affected by the degree to which they feel welcomed within any particular spatial unit and one clear issue that arose in the research concerned the difference between the welcome experienced from the 'nation state' and that experienced from the population. State institutions were associated with Britain and the immigration process, and the lack of welcome emanating from those institutions meant that the state was seen as almost uniformly unwelcoming. The asylum process is the most prominent example of this unwelcoming state behaviour, as well as being the example with the most enduring effects, as expressed by one research participant, 'for the British society it's okay they say welcome to Britain, and for the Home Office...... is not welcome in Britain' (E 606). Such sentiments are widespread and can negate positive developments in integration, such that some refugees in this research made a decision not to engage with anything that involves the UK state.

Policy at the moment operates against integration by creating time lags in labour market access; preventing local integration through housing decisions; discouraging engagement with state institutions; contributing to social isolation and health and well-being problems, all of which create issues which national, sub-national and local governments must then address. The Scottish context in which integration either occurs or does not is therefore important. The Scottish Government, for example, has a different discourse around migration, and it is widely accepted that the political climate around migration issues is different in Scotland than in the UK as a whole. This more positive political climate reflects and/or refracts opinion polls that show Scots to be less negative about migration broadly and asylum more specifically than the UK as a whole (Blinder 2014). Local communities 
have also on occasion rallied to the support of their asylum seeking neighbours subject to removal from the dispersal area to which they were sent by the Home Office and civil society organisations have been active in their areas of work in mitigating the effects of UK policy. The S cottish Government also have a more politically progressive approach in some of the policy areas in which they have jurisdiction. However, it is not yet known whether this policy divergence and different political climate leads to different experiences and/or outcomes as comparative data is lacking (Cebulla et al 2010). What can be said, however, is that present immigration policy and practice at the UK level makes integration increasingly challenging and so successful integration, however measured, is therefore difficult under the present immigration policy architecture.

\section{References}

Ager, A \& Strang, A, (2004), Indicators of Integration. A Home Office Development and Practice Report. Communication Development Unit, Room 264, Home Office, 50 Queen Anne's Gate, London SW 1H 9AT.

Ager, A. \& Strang, A (2008) 'Understanding integration: a conceptual framework.' J ournal of Refugee Studies 21 (2) 166-191

Bloch, Alice (2000) A New Era or More of the Same: Asylum policy in the UK. J ournal of Refugee Studies 13:1 29-42

Bloch, A. (2007). Refugees in the UK labour market: The conflict between economic integration and policy-led labour market restriction. J ournal of Social Policy, 37 21-36. 
Blunkett, David (2001) 'It's not about cricket tests'

http://www.guardian.co.uk/politics/2001/dec/14/race.uk

Bowes. A Ferguson, I. and Sim, D. (2009) 'Asylum policy and asylum

experiences: interactions in a Scottish context' Ethnic and Racial Studies: 1-21.

Cairney P (2012) Intergovernmental Relations in Scotland: what was the SNP

effect? , B ritish J ournal of Politics and International Relations, 14 (2), pp. 231-249.

Cameron Speech (2011) Radicalism and Islam http://www.newstatesman.com/blogs/thestaggers/2011/02/terrorism-islam-ideology

Castles, Stephen (2004) Why migration policies fail Ethnic and Racial Studies 27:2 205227

Castles, Stephen and Miller, Mark J ., (2009) The Age of Migration: International

Population Movements in the Modern World. Fourth edition, Basingstoke and New York:

Palgrave-Macmillan and Guilford

Cebulla, A, Daniel M \& Zuruman A (2010) Spotlight on Refugee Integration: Findings

from the Survey of New Refugees in the United Kingdom Home Office Research Report 37 London RDS Home Office

Christie, Campbell (2011) Report on the Future Delivery of Public Services

http://www.scotland.gov.uk/About/R eview/publicservicescommission

Cohen, Robin (2006) Migration and its enemies: global capital, migrant labour and the nation-state Ashgate England

Crawley, Heavan (2010) Chance or Choice? Understanding Why Asylum Seekers Come to the UK http://www.refugeecouncil.org.uk/policy_research/research

Department for W ork and Pensions (2003) Working to Rebuild Lives: A preliminary report towards a refugee employment strategy http://www.dwp.gov.uk/docs/main-rep.pdf

Department for Communities and Local Government (2012) Creating the conditions for integration Crown Copyright

Dorey, Peter (2010) A Poverty of Imagination: Blaming the Poor for Inequality The Political Quarterly Vol. 81, No. 3333-343

Favell Adrian (1998) Multicultural race relations in B ritain: Problems of interpretation and explanation in J oppke, Christian Ed Challenge to the nation-state; immigration in western Europe and the united states Oxford University Press US

Given, Lisa (2008) The Scottish Health Survey

http://www.scotland.gov.uk/P ublications/2009/09/28102003/7

Hammar, Tomas (2006) European Immigration Policy: A Comparative Study in The Migration Reader; Exploring Politics and Policies Messina and Lahav (Eds) Lynne Rienner Publishers US 
Hansen, Randall (2000) Migration Policy in the 1970s and 1980s: The Institutional Origins of British Restrictionism in Citizenship and Immigration in Post-War Britain; The Institutional Origins of a Multicultural Nation Oxford University Press US

Home Office (2000) Full and Equal Citizens. A Strategy for the Integration of Refugees into the United Kingdom, Croydon: Home Office.

Home Office (2005a) Integration Matters, Croydon: Home O ffice.

Independent Asylum Commission (2007) Fit for Purpose Yet?

http://www.independentasylumcommission.org.uk/files/F it\%20for\%20Purpose $\% 20 \mathrm{Y}$ et.pdf

J oppke, Christian (1999) Immigration and the Nation State; the United States, Germany and Great Britain Oxford University Press US

J oppke, Christian (2007) Beyond national models: Civic integration policies for immigrants in Western Europe West European Politics Vol 30 No 1

Kostakopoulou, Dora (2010) Matters of control: integration tests, naturalisation reform and probationary citizenship in the United Kingdom. J ournal of Ethnic and Migration Studies 36:5 829-846.

Levitas, Ruth A (2005) The Inclusive Society? Social Exclusion and New Labour Palgrave Macmillan.

Levitas, R. A., Pantazis, C., Fahmy, E., Gordon, D., Lloyd, E. H. R. R. \& Patsios, D. (2007) The Multi-dimensional Analys is of Social Exclusion Department for Communities and Local Government (DCLG)

Majone, Giandomenico (1998) Public Policy and Administration: Ideas, Interests and Institutions in Goodin and Klingemann (Eds) - A New Handbook of Political Science Oxford University Press New York

Miles, Robert (1993) Racism after 'race relations Routledge London

Mitchell, J ames (2002), Towards a New Constitutional Settlement? , in Colin Hay (ed.), British Politics Today, Cambridge, Polity Press, pp.237-258.

Mooney, Gerry and Williams, Charlotte (2006) Forging new 'ways of life'? Social policy and nation building in devolved Scotland and Wales Critical Social Policy Vol 26 608629

Mulvey, Gareth (2013) In search of normality: Refugee Integration in Scotland http://www.scottishrefugeecouncil.org.uk/policy_and_research/research_reports

Pierson, Paul (2006) 'Public Policies as Institutions' in Shapiro, Skowronek and Galvin (Eds) Rethinking Political Institutions: The Art of the State by New Y ork University Press New York 114-134

Phillimore, J enny (2011) Refugees, Acculturation Strategies, Stress and Integration J ournal of Social Policy 40:3 575-593

Phillimore, J , Goodson, L (2008), Making a Place in the Global City - The relevance of indicators of integration, J ournal of Refugee Studies, 21: 305-325. 
Robinson, Vaughn \& Segrott, J eremy. (2002) Understanding the Decision-Making of Asylum Seekers, Home Office Research Series Paper 243 (74pp).

Scholten, Peter W A (2013) Agenda dynamics and the multi-level governance of intractable policy controversies: the case of migrant integration in the Netherlands Policy Sciences 46:2 217-236

Scottish Household Survey (2010) Scotland's People Annual report: Results from 2009 Scottish Household Survey http://www.scotland.gov.uk/P ublications/2010/08/25092046/0

Sim, Duncan (2009) 'This is my village now' Post-status refugee needs and experiences in Glasgow Glasgow Campaign to Welcome Refugees

http://communityinfosource.files.wordpress.com/2008/12/this_is_my_village_now.pdf

Simpson, Ludi (2012) More segregation or more mixing?

http://www.ethnicity.ac.uk/census/869_CCSR_Bulletin_More_segregation_or_more_mixing_ v7NW.pdf

Smyth Geraldine, Kum Henry (2010) When they don't use it they will lose it':

Professionals, deprofessionalization and reprofessionalization : the case of refugee teachers in Scotland J ournal of R efugee Studies Vol 23, No. 4, pp. 503-522

Solomos, J ohn (2003) Race and Racism in Britain Palgrave MacMillan UK

Somerville, W ill (2007) Immigration under New Labour The Policy Press Bristol

Souter, J ames (2011) Asylum decision-making in the UK: dis belief or denial?

http://www.opendemocracy.net/5050/james-souter/asylum-decision-making-in-uk-disbeliefor-denial

Spencer, Sarah (2011) The Migration Debate P olicy Press Bristol

Stewart, Emma (2007) Addressing the challenges facing refugee doctors in the UK Local Economy, 22 (4). pp. 409-417.

Stewart, Emma (2009) (Unpublished) Integration and onward migration of refugees in Scotland: preliminary evidence from the SUNRISE database. http://strathprints.strath.ac.uk/26907/

Stewart, Emma \& Mulvey, Gareth Mulvey (2013 Forthcoming) Seeking safety beyond refuge: the impact of immigration and citizenship policy upon refugees in the UK J ournal of Ethnic and Migration Studies

Threadgold, Terry and Geoff Court, 2005, Refugee Inclusion: A Literature Review. Produced for the Welsh R efugee Council and the Welsh Assembly Government.

Weir, Margaret (2006) When Does Politics Create Policy? The Organizational Politics of Change in Shapiro, Skowronek and Galvin (Eds) Rethinking Political Institutions: The Art of the State New York University Press New York 171-186 